\title{
ACCOUNTING AND ACCOUNTABILITY BY PROVINCIAL COUNCILS IN FIJI; THE CASE OF NAMOSI ${ }^{1}$
}

\author{
Authors \\ Nacanieli Rika * \\ Masilina Tuiloa \\ Nathaniel Tuiseke \\ Si’ata Finau-Tavite \\ School of Accounting and Finance \\ University of the South Pacific \\ Suva, FIJI
}

\begin{abstract}
The aim of this paper is twofold: firstly to examine how the concepts of accounting and accountability are understood by indigenous Fijians; and secondly to examine the role of accounting in the accountability of provincial councils.

Provincial councils are part of the Fijian Administration, which runs alongside the central government but applies only to indigenous Fijians. The Fijian Administration was introduced by the British colonial administration in the late 1800s as a mechanism for controlling indigenous Fijians. It has undergone several reviews resulting from criticisms that it has failed to fulfill the aspirations of indigenous Fijians.
\end{abstract}

There is evidence of implied and actual accountability by indigenous Fijians in Namosi. This is supported by monitoring mechanisms established by provincial offices. On the other hand, neither the Fijian Affairs Board nor the Namosi Provincial Council appears to take serious responsibility for accounting to indigenous Fijians in the province. Sadly, there is little evidence to demonstrate an explicit accountability to indigenous Fijians. Significant scope exists for improving the standard of accounting and accountability by provincial councils.

This study contributes to understanding the role of accounting among indigenous peoples, in the context of inherited colonial structures. It also represents accounting research conducted by indigenous academics, primarily in the Fijian language. This enables an examination of how language frames understanding of accounting concepts.

Keywords -accountability, accounting, Fijian Administration, indigenous Fijians, power distance, provincial councils.

*Corresponding Author.

\section{INTRODUCTION}

The role of accounting among indigenous peoples is a relatively recent field of accounting research. Within the accounting literature, Neu (2000) observes considerable resistance to recognition of the role that accounting has played in subjectifying indigenous

\footnotetext{
${ }^{1}$ The authors gratefully acknowledge comments provided by Professor Michael White of USP as well as three anonymous reviewers. Sincere appreciation is also extended to all those who participated in interviews as part of this research.
} 
peoples. This includes explicit resistance by those who assert the neutrality of accounting and a more subtle form of resistance which recognizes the plight of indigenous peoples, but ignores the contribution of accounting towards that plight. The role of accounting in this regard was recognised in 2000 through a special edition of the Accounting, Auditing and Accountability Journal which focused on the interface between accounting, indigenous cultures and indigenous peoples.

While the literature on this subject is growing, few studies have explored how accounting has been misrepresented to and misinterpreted by indigenous societies or how accounting can improve accountability within those societies. This may be related to the under-representation of indigenous peoples among accounting academics, which provides further evidence of their general dispossession, oppression and silencing (Gallhofer and Chew, 2000).

In this paper, an indigenous Fijian or $i$ taukei ${ }^{2}$ is defined according to Section 2 of the Fijian Affairs Act, and includes

“...every member of an aboriginal race indigenous to Fiji and also includes every member of an aboriginal race indigenous to Melanesia, Micronesia or Polynesia living in Fiji and who has elected to live in a Fijian village” (Fijian Affairs Act, 1978)

In relation to the latter category of indigenous people, the reference to Fijian villages is important, since it assumes two things: they have adopted or accepted Fijian customs and traditions; and they are governed by the Fijian Administration.

Gallhofer and Chew (2000) identified several reasons for considering indigenous peoples as a specific group, beginning with the fact that they have experienced colonial rule despite having inhabited lands well before colonisation. The effect of colonialism on indigenous peoples is receiving greater recognition, with growing concern to respect their cultures and facilitate their development, as exemplified by the United Nations Declaration on Rights of Indigenous Peoples, adopted in September 2007. Indigenous peoples are actively involved in challenging Western policies, institutions and attitudes, which are seen as discriminatory towards them. In this respect, it is important to address the structures and systems that were initially set up to regulate relations between settlers and indigenous peoples. Some of these structures still exist today (Gallhofer and Chew, 2000).

This paper focuses on one such structure, namely the Fijian Administration, which was established by the British colonial administration for the specific purpose of controlling indigenous Fijians. While it was intended as a temporary mechanism, to be dismantled upon independence, it has become institutionalised to the extent that many Fijians now embrace the structure as part of their cultural heritage (Durutalo, 1997; Davie, 2000; Qalo, 2006).

In establishing the Fijian Administration, Davie (2006) argues that the colonial administration capitalized on the large power distance in Fijian culture while simultaneously exploiting the indigenous caste system to reinforce chiefly rule. This led to the establishment of collaborating elites, who have survived well into the post-colonial era. The selective accountability practiced by chiefs during the colonial era is still evident today, within provincial councils and the Fijian Administration in general. It is an example of responsibility

\footnotetext{
${ }^{2}$ Fijian words are italicized and defined either within the text or in the glossary.
} 
failure (Gregory, 1995), whereby chiefs and appointed officers fail to accept responsibility for their actions to the people that they represent or serve (Davie, 2006).

The need for greater accountability to indigenous Fijians is further illustrated by another three contemporary issues. First, a PriceWaterhouseCoopers (2000) review of the Fijian Administration reported inadequate practices for budgeting, accounting and monitoring. A common complaint raised by participants in the survey was the lack of accountability and transparency in relation to provincial levies.

Second, disputes over chiefly titles are frequently linked to the monetary implications of the title (Durutalo, 1997; Seruvakula, 2000). 87 percent of land in Fiji is classified as native (Fijian) land; sale of this land is prohibited under the constitution. Native land is owned collectively, with 30 percent of income from land leases reserved for chiefs at various levels of the hierarchy shown in Figure 1 below. Such a system leads to unequal rewards, which indigenous Fijians are beginning to question more directly, openly and frequently. This is a significant trend, given the large power distances that characterise indigenous Fijian society (Chand, 2003; Davie, 2006).

Third, the media has documented many cases where resource owners have denied access to developers, in protest that they have not been fairly compensated for use of their land, forests and fishing grounds. Such disputes have particularly hindered development in agriculture (primarily sugar cane farming), forestry (most recently mahogany) and tourism (for example, the Natadola Resort Development Project (Naivaluwaqa, 2007)). While such action by landowners could sometimes be frivolous, there may also be cases where they have genuinely received a raw deal, as a result of dishonesty and/or incompetence by those negotiating on their behalf. For instance, Sharma (1999) highlighted that Fijian landowners neither control not manage their own land. Instead, the power is constitutionally vested in the Native Land Trust Board (NLTB) which acts like the "big brother" that makes decisions for them. In doing so, NLTB has failed to directly consult with the very landowners whose interests it is supposed to protect. Whether genuine or frivolous, resultant intervention by landowners reveals a greater awareness by indigenous Fijians of their right to participate equitably in decisions concerning, and the monetary rewards derived from, their natural resources.

In light of the foregoing, there is an urgent need to develop appropriate accounting frameworks, which will adequately address the needs of indigenous Fijians. This will ensure that provincial finances are managed prudently, accounting information is tabled and communicated clearly, proceeds are distributed fairly and valuable natural resources are developed in a sustainable manner.

Since 1949, a total of eight reviews have been conducted into the Fijian Administration (Ministry of Information, 2007). Although some of them have considered issues of accountability, this has generally been limited to the structure of the Fijian Administration, while failing to focus in detail on the systems for accounting to indigenous Fijians. This paper seeks to document the current level of reporting and understand what indigenous Fijians want to be reported. These are critical steps in facilitating greater accountability.

The remainder of this paper is organized as follows. The next section summarises the structure and historical development of the Fijian Administration, which provides the context for the research and subsequent discussion. The third section presents a pre-colonial system of accountability while the fourth section outlines the research strategy and methods adopted in 
the study. Findings are presented and analysed in the fifth section. The paper concludes by suggesting possible areas for further research.

\section{THE FIJIAN ADMINISTRATION}

The Fijian Administration oversees fourteen provinces or yasana whose present boundaries were determined in 1944, following a review conducted by Ratu Sir Lala Sukuna, and which vary in land area, population and natural resources. While it can be described as a parallel system of government which runs alongside the central government, there are several ways in which it differs from other local governments in Fiji. First, it applies only to indigenous Fijians, while municipal governments have jurisdiction over citizens from all ethnic groups. Second, it transcends rural and urban boundaries, whereas other local government authorities are restricted to municipal areas. Third, all members of provincial, district and village councils are nominated, often through consensus. On the other hand, municipal authorities are managed by political dominance, in the sense that ratepayers elect councilors, who then elect the mayor. Finally, municipal governments continue to exercise substantial legal powers, which the Fijian Administration lost when provincial courts and magistrates were abolished in 1968.

\section{Structure}

The system is hierarchical in nature, with the Bose Levu Vakaturaga $\left(\mathrm{BLV}^{3}\right)$ or Great Council of Chiefs (GCC) at its apex, as depicted in Figure 1 below.

Figure 1 Fijian Administration

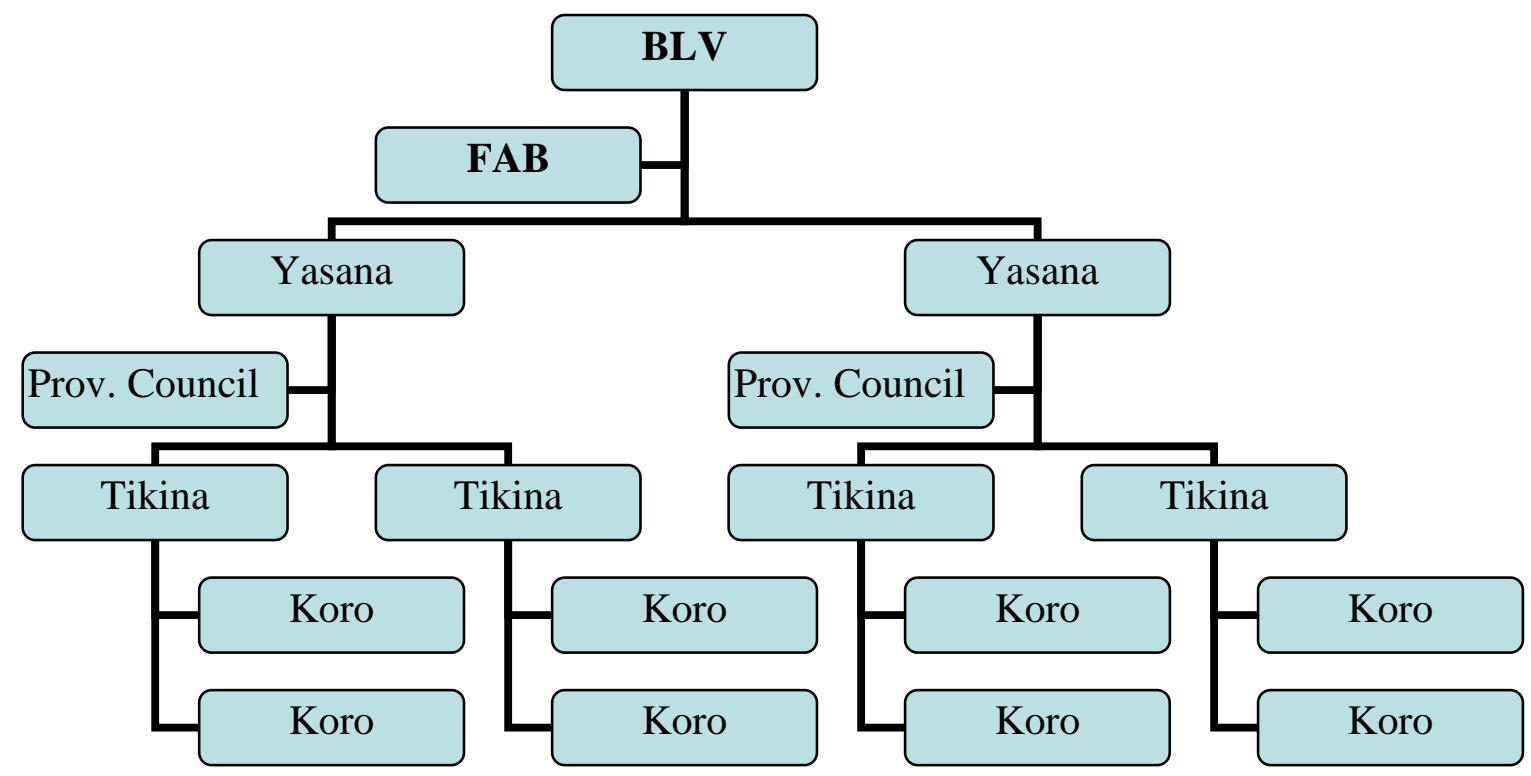

The number of districts or tikina and villages or koro varies from one case to another.

\section{Adapted from Durutalo (1997)}

The BLV is the ultimate authority on things Fijian and consists of 55 members, including three representatives from each province, one of whom is the paramount chief of the province. $\mathrm{He}^{4}$ attends by virtue of his title while the other two representatives are nominated

\footnotetext{
${ }^{3}$ This abbreviation is used throughout the paper, rather than GCC.

${ }^{4}$ At the time of writing, only one of the 14 paramount chiefs is a woman.
} 
by the provincial council. The Fijian Affairs Board (FAB) is the executive arm and secretariat of the BLV. In addition, the FAB monitors and regulates the affairs of the provincial councils as part of its secretariat function. Each province has its own secretariat or provincial administration, headed by a Roko Tui.

At the village level, monthly meetings are held under the chairmanship of the village chief. Each quarter there is a meeting of chiefs and turaga ni koro or village headmen from all villages in the district. This forum determines development priorities for the district. The provincial office is ultimately responsible for coordinating development, through requests for government grants and disbursement of funds. The district meeting nominates one of its members as a representative to the provincial council meeting, which is held twice a year. Known as the mata ni tikina, this person is responsible for raising issues concerning the district at the provincial level. Following the provincial council meeting, the mata ni tikina is responsible for disseminating outcomes at the next district meeting while turaga ni koro are responsible for communicating decisions back to their own villages.

Based on research in the province of Nadroga and Navosa, Belshaw (1964) argued that the system of Fijian administration increases the separation of the administration from the villager. He observed that it was difficult for Fijians to speak directly against the system at a provincial council meeting. One of the few with the confidence to openly express his dissatisfaction was the buli of the Baravi tikina, who said:

"the present system gave too much power to the chiefs and entrenched leaders, so that the rest of the people didn’t count” (Belshaw, 1964:226)

In a similar vein, Durutalo (1997) argued that provincial councils play an important role in maintaining patron-client relationships within Fijian society, which were first introduced by the colonial administration. Such relationships often develop between people of unequal wealth, status and influence. They depend upon reciprocity, primarily in the exchange of goods and services. The client may receive material assistance while the patron receives resources of a less tangible nature. Those at lower levels of the hierarchy may have little opportunity to question, let alone influence decision-making. Even if such opportunities are provided, traditional values such as deference may hinder them from openly expressing dissent (Belshaw, 1964).

\section{HISTORICAL DEVELOPMENT}

Fiji was ceded to Great Britain in 1874. Two years later, the Fijian Administration or Matanitu $i$ Taukei was created by the second governor, Sir Arthur Gordon. In order to establish this system of indirect rule over indigenous Fijians, it was necessary to divide the colony into 12 provinces. As such, Durutalo (1997) has defined a Fijian province as a geographical entity which was carved out of political necessity. The chiefs of each province became members of the BLV. Every province, district and village was placed under the leadership of a chief and it was generally chiefs sympathetic to the colonial presence who were appointed to hold remunerative positions (Durutalo, 1997). So from the very outset, many appointments in the provincial administration were not based on achievement. On the contrary, they were based on ascription, with a fundamental requirement being demonstrated loyalty to the colonial state. There is no evidence that loyalty or accountability to the people was considered when making such appointments.

Several reviews of the Fijian Administration recommended decreasing its role and integrating Fijians into the mainstream (McDougall, 1957; Spate, 1959; Burns, 1960). More 
recent reviews have been conducted by Cole et al (1985), PriceWaterhouseCoopers (2002), Ratu Tu'akitau Cokanauto in 2003 and the Maxumise consulting agency in 2006. These studies were commissioned due to concern that the structure and systems of Fijian Administration were no longer adequate to meet the evolving concerns, needs and interests of Fijians, in light of the market economy, urbanization and education (PriceWaterhouseCoopers, 2002).

The Maxumise report had been endorsed by the BLV as well as Cabinet, before political events in December 2006 interrupted its implementation. In August 2007, the interim government appointed a six-member task force to review the BLV. According to its terms of reference, the committee was to consider issues such as accountability, ethics and honesty (Ministry of Information, 2007). It is interesting to note that this review is again chaired by Ratu Tu'akitau Cokanauto. One reason why the Maxumise report was more readily accepted was because it sought to identify and employ governance structures that existed in precolonial Fijian society, some of which have much weaker influence today. The next section discusses accountability within such a structure.

\section{PRE-COLONIAL ACCOUNTABILITY STRUCTURES}

Historically, when a tribe settled in a new area, it would allocate distinct functions to its members and these functions were often allocated on the basis of existing mataqali (Seruvakaula, 2000). The seven distinct functions included: the turaga or chief; the sauturaga, who were responsible for supporting chiefly authority; the matanivanua, or official heralds and ambassadors; the bete or priests; the bati or warriors; the gonedau or fishermen; and the mataisau or craftsmen (Tagi, 1991). In contemporary society, some of these roles have lost their traditional essence and have been taken over by the government, churches, individuals and other groups. For example, the role of the bete has been appropriated by Christian ministers and priests (Seruvakula, 2000).

Another role that has become quiet in modern society is that of the sauturaga. Seruvakula (2000) identifies nine traditional roles of the sauturaga. These include providing advice to the chief when needed and ensuring that concerns of the vanua are brought to the chief for due consideration. It is also their responsibility to confront the chief when his decisions or behaviour are deemed to be inappropriate. Finally, they are responsible for allocating and distributing traditional items of wealth, during ceremonies. In this regard, they are particularly renowned for their wisdom.

Three pertinent observations can be made here. One is the role of the sauturaga in allocating and distributing wealth during significant events such as the marriage and death of a chief. Each group attending such an event would contribute traditional items of wealth, which would either be consumed during the ceremonies or re-distributed among the contributories. This process of wealth distribution is similar to distribution of company profits in the form of dividends and provides some evidence of a traditional form of accounting. However, contribution and distribution is based on reciprocity, rather than legal obligations and statutory regulations which prevail in the case of a company.

Second, it becomes apparent that the traditional social structure makes the chief accountable to the people, who are able to express their dissatisfaction through the office of the sauturaga. The third observation relates to replacement of traditional structures by western ones. In pre-colonial times, the sauturaga would identify suitable heirs for the chiefly title. They would then select and install the most suitable candidate through consensus, based on an agreed set of desirable leadership qualities. In this context, the chiefly title was 
conferred on the basis of achievement rather than birth. However, establishment of the Fijian Administration, with its written records has established in concrete what was essentially a fluid process. As such, it has constructed a system of hereditary leadership (Seruvakula, 2000). This may also have weakened the power base of the sauturaga, since disputes over chiefly titles are now decided by the Veitarogi Vanua or Native Lands Commission (NLC), rather than the consensus of the people, under the wise counsel of the sauturaga. This provides support for the observation that the colonial administration created a collaborating elite among the ruling chiefs (Davie, 2006), while simultaneously silencing other groups and usurping their traditional roles or rendering them redundant.

\section{RESEARCH DESIGN}

The research reported in this paper sought to document indigenous Fijian understanding of accounting and accountability. Second, it examined the role played by accounting in the accountability of provincial councils to indigenous Fijians. Concurrently, it examined the kinds of information that indigenous Fijians would like provincial councils to provide.

\section{Research Methodology and Methods}

Previous accounting research concerning indigenous Fijians has relied almost entirely on archival research (Davie 2000, 2006; Reddy and Singh, 2007). These studies have also been conducted by non-indigenous people. In this regard, the authors had a distinct advantage since two of them are indigenous Fijians who speak Fijian fluently. Here it must be noted that the Fijian language consists of various dialects. The Bauan dialect is taught in schools and generally used as the lingua franca, having been selected by the colonial administration - yet another structure imposed to control a colonized people.

The indigenous Fijian authors have been able to maintain a certain distance from the issues since they come from a different province to the one being studied in this paper. Although the other two authors are not Fijian, they are also indigenous people. This significantly eliminated barriers which could be associated with suspicion of researchers from other ethnic groups in Fiji.

As outlined elsewhere in the paper, Fijian provincial councils are a human construct, developed by the British colonial administration in the late $19^{\text {th }}$ century. Any study of the councils must consider this factor, not only as a historical anecdote but more importantly in shaping the nature of the research. Since the concepts of accounting and accountability are also human constructs, this study acknowledges the possibility that the way they are interpreted may differ among individuals and groups within society. This necessitated a holistic epistemology that allowed for multiple meanings and complex possibilities. As such, the research took the form of a case study, involving an in-depth examination of provincial councils through individual and group interviews, observation of meetings and document analysis. Documents analysed included: the Fijian Affairs Act, previous reviews of the Fijian Administration; audited and unaudited financial statements; audit reports; and additional documents obtained from provincial offices during the course of interviews, such as budgets and corporate plans.

A total of eight individual interviews were conducted. Of these, four were with staff of Namosi and Serua provincial councils, including Roko Tui and Provincial Treasurers, one was with the mata ni tikina of Veivatuloa district and one was with the turaga-ni-koro of Veivatuloa village. Questions for these interviews are available from the authors and were administered in Fijian, except for those with the Provincial Treasurers, which were conducted in English, due to the use of technical accounting terms which have not been translated into 
Fijian. Following the interviews of provincial councils, an interview was conducted with the managing director of the Maxumise Consulting Agency, which conducted an unpublished review of the Fijian Administration in 2006. The next interview was with a Fijian chief who has participated in two reviews of the Fijian Administration. Both these interviews were conducted in English. Because their report findings have not been made public, these latter two interviews were documented in the form of field notes, rather than an audio-recording.

In addition, two group interviews were conducted in Veivatuloa village. The first group consisted of five women between the ages of 20 and 60. It included three representatives of the women's group (Soqosoqo Vakamarama), one of whom is also the wife of the turaga ni koro. Another of the women is a first cousin of the village chief (who is also the paramount chief of the province). The second group consisted of eight males, including heads of households (Liuliu ni vuvale se i tokatoka), leader of the youth group (Soqosoqo ni Cauravou kei na Goneyalewa), youths (Taba Gone) and senior citizens (Taba Qase). The group interviews were all conducted in Fijian and recorded on video. They were subsequently translated, transcribed and analysed by the authors, collectively. The head teacher of Veivatuloa District School also provided his own written answers (in Fijian) to the interview questions.

Subsequently, one of the authors attended a meeting of the Namosi Provincial Council, as an observer. Finally, a meeting was conducted with two staff of the Fiji Museum; the registrar and a senior field officer in archaeology. This was expressly to substantiate findings in relation to traditional structures of accountability.

\section{Research Sites}

Due to the complexity of the research exercise, it was decided to commence with a pilot study, which would enable research methods and instruments to be trialed and revised if necessary. Two provinces were initially selected for inclusion in this pilot study. They are Namosi and Serua, which are neighbouring provinces located within 50 kilometres of Suva City. Many of the villages in these provinces are located along the main highway. In terms of population size, Namosi is the smallest province in the whole of Fiji. When size is measured according to the number of villages, Namosi and Serua are jointly classified as the smallest provinces in Fiji, with less than 30 villages each. Although staff of the Serua Provincial Council were interviewed, it was decided to suspend further research following several misunderstandings regarding scheduling of village interviews.

Namosi is typical of all Fiji's provinces in at least three respects. First, all provinces are governed by the Fijian Administration, so the same structures and regulations apply in Namosi as elsewhere. Second, there is little variation in Fijian social structure (see Figure 1) and cultural values across provinces. Thirdly, reviews of the Fijian Administration indicate similarity in the issues raised by representatives from each province.

The Namosi Provincial Office is located in the township of Navua. In selecting the village for group interviews, a cluster approach was adopted, with selection of one village in the tikina located closest to the town along the highway. The chosen village in Namosi was Veivatuloa, which is located 10 kilometres from Navua. It is one of seven villages in the Veivatuloa district and also the seat of the paramount chief of the province, the Tui Namosi. The mata ni tikina for the district lives on the outskirts of the village boundary. Given the proximity of Veivatuloa to the Provincial Office and the mata ni tikina, it was initially thought that levels of accountability there might be higher than elsewhere in Namosi. 
There are four other districts in the province of Namosi. In a previous study of a village in a different district of Namosi, Mamak (1976) found that the major differences among people of the province related to dialects, Christian denomination (generally Catholic or Methodist) and perceptions about intra-provincial economic development (relatively more versus relatively less). Of the 45 heads of households interviewed, only seven identified differences relating to traditions (either more or less traditional than other villages in the province). Two other considerations should be noted; Namosi is a small province and the whole province belongs to one yavusa or tribe. When these findings are considered together, it is quite possible that the findings from Veivatuloa village may be indicative of the province in general.

\section{DISCUSSION AND ANALYSIS}

The challenge of translating financial concepts into the Fijian language was acknowledged by one of the interviewees, who cited examples of terms that relate to capital markets. This is supported by a review of the FAB Standing Orders for Accounting ${ }^{5}$, which outlines internal control procedures for: the receipt, custody and disbursement of revenue; accounting and audit; and the inspection of accounts (FAB, 1949). Although the document is translated into Fijian, a review of the Fijian version reveals that terms such as "investment," "audit," and "cheque” are all expressed in English. In attempting to understand this, it is surmised that some concepts which are readily used and accepted in Western systems of accounting may not have a well-aligned equivalent within indigenous Fijian society and language. Consequently, the research explored what indigenous Fijians understand by the term accounting and how this understanding may have developed.

\section{Understanding of accounting}

Interviewees generally explained the concept of accounting as relating to money ( $\mathrm{na}$ veika vakailavo) or financial statements (tukutuku vakailavo). Such explanations emphasise the form of accounting, rather than its function. In the Standing Orders (FAB, 1949), an accountant is translated as dau ni vika, which broadly translates to "one who is an expert with numbers.” The word vika is borrowed from the English word figure, in the sense of a numeral. This translation also appears in a Fijian-English dictionary (Capell, 1991) and accountants are still known as dau ni vika in Fiji today, as evidenced by interview responses. Obviously, this term could (better) describe a mathematician, so the translation has captured the form of accounting as opposed to its substance.

Evidently the accountant's stewardship responsibility (let alone the expertise associated with providing information for decision making) has been lost in the translation. Dau ni vika would seem to emphasise the calculations involved in accounting as an end in themselves, rather than a means to providing an account. This could be expected to impose significant limitations on the way that accounting and accountants are perceived by indigenous Fijians.

It appears that in translating terms, the early colonial administrators used words which misrepresented the meaning of accounting, leading to misinterpretation by subsequent generations of indigenous Fijians. Another example is the Fijian translation for bookkeeper, which is vunivola. It literally means "originator of the letter (or book)" and is also used to describe the role of secretary, scribe or clerk (Capell, 1991). There is no indication or implication of why the bookkeeper must maintain such books.

A more appropriate (and less arrogant) approach to translation might have commenced with an exploration of pre-existing concepts within Fijian society, such as the ceremonial

\footnotetext{
${ }^{5}$ Hereinafter referred to as Standing Orders
} 
exchange of wealth discussed earlier, under traditional accountability structures. When it is absolutely necessary to add words to the Fijian vocabulary, care must be taken to adequately capture their substance and function.

\section{Understanding of accountability}

Unlike accounting, there is no single word in the Fijian language that readily captures the notion of accountability, as evident from a review of Fijian language dictionaries (Hazlewood, 1914; Capell, 1991). Any attempts to introduce and develop concepts of accountability within the Fijian Administration are likely to be hindered, unless indigenous Fijians share a common understanding of what the term means.

In its corporate plan, the Namosi Provincial Council lists accountability among its eleven key values. However, in explaining what accountability means, the document states that the council

“will be accountable for performance and results” (Namosi Provincial Council, 2006).

This explanation involves circular reasoning, where being accountable is used to explain accountability. Since the explanation omits any reference to responsibility for providing an explanation of decisions and actions, it raises the possibility that the council may not be sure of what accountability entails.

Based on the interviews conducted, it is evident that the concept of accountability has different meanings to different people within the Fijian Administration. In some cases, these meanings only capture some aspects of accountability, but not others. Some of the definitions provided by interviewees are discussed below.

Question

How would you explain the term `accountability’ in Fijian?

\section{$\underline{\text { Roko Tui A }}$}

“Mo nuitaki e na i tavi 'o qarava se na cakacaka 'o cakava .... Mo vakabauti e na veika vakailavo ... Mo dina (e na nomu i tutu vaka i liuliu)” (Personal Communication, August $27^{\text {th }}$ 2007)

Translated as

"To be trustworthy in your work and responsibilities ... to have credibility in money matters ... to be faithful in your leadership role.”

He also recognised that accountability is much broader than-and not restricted tofinances.

Citing Nayacakalou (1975), Qalo (1993) argues that the concept of dina is too general and imprecise, because it may be translated as trustworthiness, faithfulness or even frankness. He warns that dina may become a weapon

"when used by chiefs coupled with the habit of not asking questions in the Fijian traditional context" (Qalo, 1993: 52).

since 
"It is still considered disrespectful to directly question the validity of a statement made by a ... chief ... or senior village member” (Qalo, 1993: 52).

Hence, any statement or explanation provided by a chief may potentially be regarded as dina, in the sense that it carries authority and is therefore legitimised. Because of the large power distance in Fijian society, his people accept this statement out of loyalty and obedience. Dina is a weapon in the sense that the statement itself may be incomplete, unsubstantiated or vague.

\section{$\underline{\text { Roko Tui B }}$}

"Na dodonu ... me vakadodonutaki (me kua ni veve) ... mo muria vakadodonu ... kua na cakacaka vakailawaki ..." (Personal Communication, August $27^{\text {th }} 2007$ )

\section{Translated as}

"What is right ... to be aligned (not crooked) ... to follow correctly ... don't work in a cunning or deceitful manner"

He also asserted that his ancestors did not practice cunning and deceit. In fact, such behaviour was viewed as disgraceful. It was a serious misdemeanour, punishable by caning or even banishment from the village.

This definition appears to be more closely aligned with standards for ethical behaviour than accountability since it relates to work practices but makes no mention of providing an account. It may imply that following procedures correctly is a sufficient condition for accountability, rather than a necessary one.

Two interesting definitions were obtained during our visit to Veivatuloa village; one was explicitly stated in writing while the other was inferred from an interview.

\section{$\underline{\text { Head Teacher }}$}

"Veika taucoko e caka me vakamatatataki vakaivola ka vakaraitaki vakamatata vei ira e dodonu me ra kila" (Personal Communication, October $26^{\text {th }} 2007$ )

\section{Translated as}

"Everything that is done to provide a precise and detailed (written) record to those who should know about it."

This definition captures the notion of providing a detailed account to those who have a right to know, which in turn raises the question of who has a right to know; or to whom the provincial council is accountable. When asked to identify their stakeholders, officials at the provincial offices only mentioned two stakeholder groups, namely central government and non-government organisations (NGOs) who fund projects in the province. The villagers were only mentioned following prompting by the interviewers. In light of later findings, this suggests that accountability to villagers is perceived as less important than accountability to some other stakeholders. It is reminiscent of the view reported by Belshaw (1964), that untitled people don't count. 
In discussing the usefulness of financial reports, tabled at Provincial Council Meetings, the turaga ni koro provided the following explanation, which indicates an understanding of the rationale for accountability.

\section{$\underline{\text { Turaga ni koro }}$}

"dodonu me da raica me yaga vei keda ... me da kila na vanua e lako kina na i lavo ... baleta na i lavo ya era vakaitavi kina o ira na lewe ni koro" (Personal Communication, October $26^{\text {th }}$ 2007)

\section{Translated as}

"it's only right that we should see (the reports) so that they become useful to us ... so we know where money has been allocated ... because that money has been contributed by the villagers”

These sentiments were echoed by one of the female interviewees, who had previously worked in the Namosi Provincial Office. She reasoned that villagers bear the burden of raising provincial finances, so they should be shown how money has been used. As it is, they are regularly asked to contribute towards provincial levies, whereas they have not received any account for the use of their previous contributions. She also said that every (Women's and Youth) organisation in the village should receive a copy of financial statements from the provincial office. Based on her work experience, she felt the provincial office is not very transparent, since they do not return to villages and explain how provincial levies have been used.

In relation to accountability, the comments by the turaga ni koro and the female interviewee suggest that they are aware of the need to provide an account for funds collected and managed on behalf of a third party, although they are not familiar with the label "accountability." Most of those in the interview groups agreed that they had heard the word used on radio and television, but they did not know what it meant. During the interviews, several participants asked the interviewers to explain the meaning of accountability to them. However, such explanations could not be provided, since they might have unduly influenced answers by the interviewees.

The Fijian chief, who has participated in two reviews of the Fijian Administration, identified the broadness of accountability and explained it in the following way.

\section{$\underline{\text { Chief C }}$}

“Na i tukutuku dodonu ... na i tukutuku matata” (Personal Communication, October $\left.27^{\text {th }} 2007\right)$

which he then explained as

“...the information is clinically clear ... A person who is (clinically) clean ... clear in his dealings.”

“Dodonu vinaka na nona i tukutuku ka matata talega vei ira ka tukutuku kina ... savasava”

for which he provided the following English explanation

"Information is clean and there is nothing to hide ... everything is on the table.... It's also clear to the recipients of the information ...show responsibility right through in providing this information”

“Kevaka e buwawa se sega ni matata, kena i balebale ni sega ni savasava” 
"If it's unclear then it's not clean”

This explanation contains several terms which overlap with the previous interviewees and may be useful in synthesising a Fijian understanding of accountability. First, it involves a third party, identified as the audience or recipients of the information. Second, it places the concepts of dodonu and savasava in the context of tukutuku, thus identifying the importance of providing information which is right or accurate. Third, it uses the contrasting concepts of matata and buwawa to emphasise that information must be stated clearly or transparently.

The next section examines the role of accounting in the provincial administrations.

\section{Provincial levies}

Provinces receive revenue from two main sources. The first is an annual government grant or subvention, which covers salaries and administrative expenses. In addition, the council may raise funds by imposing annual levies on male villagers, over the age of 21 . Therefore provincial levies only apply directly to those indigenous Fijians who reside in villages. This can be traced back to the system of native taxation, introduced by Sir Arthur Gordon. Based on an assessment by the legislature, a certain amount of tax was determined for every province. The tax was charged in terms of particular agricultural produce, which the province was required to provide. It was then allocated progressively to each district and village where the burden was met through the collective effort of all adult males.

As such, one function of the Fijian Administration was to provide an efficient means of financing the colonial administration. This allowed the latter to control the indigenous population from a distance, using the authority of existing chiefs (Durutalo, 1997). Neu and Graham (2004) documented a similar phenomenon in relation to the Canadian Indian Department under the direction of Deputy Superintendent D.C. Scott at the beginning of the $20^{\text {th }}$ century. The system of provincial levies simultaneously obliged Fijians to remain in their villages and engage in productive economic activity.

In Serua, the provincial levy is charged at the rate of 10 dollars $^{6}$, while Namosi levies 40 dollars (Roko Tui Namosi, personal communication). In 2007, Veivatuloa village was required to raise 2,580 dollars, based on records provided by the Provincial Office, which showed 65 households in the village. However, interviews revealed that each adult male was actually required to contribute 50 dollars. This was explained by the fact that some villagers were excluded on the basis of prolonged illness or absence from the village.

The villagers also acknowledged that they had only met 50 percent of their obligation in 2007, due to the economic downturn associated with political events of December 2006. This had contributed to a decline in demand for produce, such as fish and pot plants, which they sell along the highway in order to generate income.

A review of meeting papers indicates that 68.1 percent of the entire provincial levy for 2007 had been collected by October 2007. A break-down by district is provided in Table 1 below, which shows that Veivatuloa village is not alone in failing to meet its target. Of the 29 villages in Namosi, 15 had paid in full, while seven had not made any payment and the remaining seven had only paid part of the levy. At district level, at least one village in four of the five districts had some arrears. It is quite evident that villages are made accountable for

\footnotetext{
${ }^{6}$ All amounts are expressed in Fijian dollars (FJD), unless stated otherwise.
} 
the levies, since their actual contributions are tabled at the meeting, in the presence of representatives from the entire province. Details for each village have been withheld in Table 1.

Table 1 Status of Provincial Levies for Namosi at October 31 2007

\begin{tabular}{|l|c|c|c|c|}
\hline $\begin{array}{l}\text { Name of } \\
\text { District }\end{array}$ & Budget & $\begin{array}{c}\text { Contributed to } \\
\text { Date }\end{array}$ & $\begin{array}{c}\text { \% Contributed } \\
\text { to date }\end{array}$ & $\begin{array}{c}\text { Outstanding } \\
\text { Contribution }\end{array}$ \\
\hline Veivatuloa & 21,284 & 11,516 & 54.1 & 9,768 \\
\hline Namosi & 8,960 & 8,047 & 89.8 & 913 \\
\hline Wainikoroiluva & 15,145 & 11,997 & 79.2 & 3,148 \\
\hline \hline Naqarawai & 8,340 & 2,780 & 33.3 & 5,560 \\
\hline \hline Veinuqa & 7,100 & 7,100 & 100.0 & Nil \\
\hline Total & $\mathbf{6 0 , 8 2 9}$ & $\mathbf{4 1 , 4 4 0}$ & $\mathbf{6 8 . 1}$ & $\mathbf{1 9 , 3 8 9}$ \\
\hline
\end{tabular}

Source: Namosi Provincial Council Meeting, October 2007

Among the meeting papers, there was no account or indication of how the provincial levies had been used. This suggests that the provincial office does not take responsibility, and is not held to account, for how it has managed and disbursed the funds.

The village meeting allocates the burden of the provincial levy equally among all economically active males in the village. During the interviews, participants acknowledged that not all villagers meet their contributions. The youth leader saw this as unfair, since everyone in the village benefits equally from amenities such as the community hall, footpaths and reticulated water systems. An elderly man recalled that in the colonial era, people were fined when they failed to pay the provincial levy but in this era of "freedom," villagers are no longer held accountable on an individual basis. The entire village is now penalised when it fails to fulfill its obligations for provincial levies as is demonstrated through the village development projects.

\section{Village development projects}

Interviewees were asked how much the province channels back into Veivatualoa each year. Here, the unanimous answer was half of the provincial levy. This was later established to be a maximum figure (PriceWaterhouseCoopers, 2002). None of the interviewees were sure how the remaining 50 percent of their annual contribution was used, although the Roko Tui Namosi had indicated that it is used to fund the provincial office and provide scholarships for secondary and tertiary education. During the group interviews, most of the women shared the perception that a higher proportion of scholarships are allocated to students from the hill districts in the province. Such views could not be substantiated due to unavailability of statistics.

Further evidence that the provincial council holds villages accountable was provided by one of the men during the group interviews. He said that when development funds are requested through the district meeting, an important consideration in evaluating the request is whether the village is up-to-date with its provincial levies. If not, the request will be declined, or at least shelved until such time as arrears have been paid in full. This was later confirmed by the mata ni tikina. 
The latest funding received from the provincial council was an amount of 1,800 dollars which provided partial funding for a village dispensary. During the visit to Veivatuloa, the authors observed the wooden frame, corrugated iron roof and some bags of cement, with an estimated value of 1,500 dollars. The village is not required to submit any accounts in relation to these projects, because all orders and payments are made by the Provincial Office, which also visits to inspect progress. Villagers informed the interviewers that the Roko Tui Namosi had inspected the structure in the week prior to the interviews.

Responsibility for completing the building now lies with the villagers. They are not entitled to further funding from the provincial council this year, since they did not meet their target. The village is planning to conduct a fundraising event in December, for which all women are required to contribute 200 dollars each. Proceeds will be used to pay the 2008 provincial levy, and settle 2007 arrears, since collection of provincial levies in Namosi closes in June the following year. The surplus will be distributed among the dispensary, village school and church.

Earlier in 2007, the village was able to successfully obtain access to electricity without any financial assistance from the provincial administration. A Veivatuloa villager who now resides in United States of America (USA) negotiated funding of approximately 35,000 dollars through an environmental NGO based in USA. This financed the poles and lines which now link the village to the national grid. Although the provincial council had no part in raising funds for the project, the village was still required to liaise with the provincial office, which assisted in negotiations with government and the electricity authority.

This discussion illustrates that no allowance is made for economic hardship faced by a village, even when it appears to be genuine and self-evident. In such cases, the village is not even eligible for government assistance, since the work of government departments within the province is coordinated in liaison with the provincial office, which declines requests from villages that are in arrears. In fact, villagers are forced to carry an even higher burden by resorting to other fundraising events, such as the one planned in Veivatuloa. Alternatively, villages can explore partnerships with NGOs, although there is significant competition for these funds and they may well require assistance in accessing them. Even in these cases, the provincial administration is able to perpetuate its control and existence, since no development at village level may proceed without its approval.

\section{Accounting reports provided by provincial councils}

Under Section 6 of Subsidiary Legislation to the Fijian Affairs Act, Provincial Councils are required to exhibit their audited financial statements at the Provincial Council Office and to publish them in such other manner as the council considers as being in accordance with local custom. The latter requirement appears to be quite vague and provides substantial latitude for selective interpretation.

The provincial treasurers stated that they do not generally provide financial reports to district council meetings, unless they are specifically requested to do so. This was confirmed by the interviewees who said that generally, provincial staff would only visit the village when it hosts the quarterly meeting of the district. No financial reports are received from the provincial office, except those tabled at the meeting of the provincial council. These are prepared and presented by representatives from FAB in Suva. Following the provincial council meeting, the village representatives provide only a verbal report to the villagers. 
Some interviewees in the village seem to be satisfied as long as a report is tabled, irrespective of its content or substance and despite the absence of detailed analysis. For instance, the turaga ni koro assured the authors that financial reports were provided at the provincial council meeting. However, when asked to produce the papers for discussion, he said that he could not find them. At the provincial council meeting, it became apparent that the mata ni tikina was recognized as the official delegate from the district. Therefore, the turaga ni koro did not even receive a copy of the meeting papers. Apart from the chairman and the Tui Namosi, the only others who received full sets of meeting papers were the five mata ni tikina and two others who represented the provincial Women's Group and Youth respectively. Apart from the status of provincial levies, no financial report was included in the meeting papers, though some discussion of provincial debts took place during the meeting.

In discussing financial statements tabled at previous provincial meetings, interviewees were asked whether those statements had been audited. One of the men answered that they should be audited and he trusts that they are audited. This indicates a high level of trust in FAB staff, and recalls the previous discussion on the concept of dina. Although provincial treasurers stated that they are "audited" by FAB several times a year, the credibility of these audits is questionable in light of later findings about the qualifications of FAB staff. This also represents another form of misrepresentation, where financial statements are labeled as audited although the external audits are six years overdue.

Interviewees were asked to identify other items of information which they would like to see included in the financial statements. The head teacher suggested that more information should be provided regarding provincial assistance for scholarships, brush-cutters and village housing projects. One of the women emphasized that villagers need to understand the formula which is used to allocate funds within the province and district. From an accounting perspective, this would seem to be a fairly straight-forward task so long as funds are allocated in accordance with transparent guidelines and an agreed ratio. The leader of the youth said that more details should be provided in relation to expenditure on village projects. This might include a separation of costs for material and labour.

The youth leader also expressed the need for FAB to provide clearer explanations and translations of terms in financial reports, which can be understood by all meeting delegates. For instance, large amounts need to be disaggregated and adequately narrated. He stated that questions are not always answered clearly and specifically by FAB staff. Although the majority of delegates at the provincial council meeting are elders, he saw his own attendance at the meeting as a responsibility. He felt that young people can better understand (financial) issues and explain them to elders, since the former are more likely to have studied accounting at school. The importance of education and training was also evident from interviews with the women. When asked whether they had ever asked for clear reports on provincial finances, they said they did not feel academically qualified to ask questions about such issues.

In theory, meetings of the district and provincial council are open to all members of the province. They may also be given the opportunity to ask questions, but they have no voting rights. At the meeting of the Namosi Provincial Council, it also became apparent that traditional protocols override normal meeting procedures. Though the paramount chief does not chair the meeting himself, his decisions are final and cannot be challenged (Qalo, 2006). For example, he may unilaterally decide to defer or terminate discussion on a certain issue, thereby "silencing" questions from the floor. 
This section highlights strengths and weaknesses in the present system. In terms of the former, district and provincial meetings are open to all members of the province and they are given speaking rights. Some individuals have studied accounting at school and are therefore in a stronger position to understand, analyse and question financial statements. Weaknesses include the generally low level of accounting knowledge among villagers, inadequate explanations provided in reports, emphasis on verbal reporting and restrictions imposed by traditional protocol.

\section{Expertise of accounting staff employed by the Fijian Administration}

Each provincial council employs a treasurer. Neither of the provincial treasurers interviewed in the study possessed formal accounting qualifications, although one of them is currently pursuing a Certificate in Business Studies. The qualifications of the provincial treasurers raise serious questions about the range of tasks and responsibilities which they can be expected to undertake proficiently.

Such a view is supported by documentation in the Fijian Affairs Act and the FAB Accounting Manual (PriceWaterhouseCoopers, 1985), which both indicate that the main tasks of the provincial treasurer relate to bookkeeping functions. Indeed, when interviewed, the treasurers identified their main role as preparing payment vouchers and issuing receipts. Monthly summaries are sent to FAB in Suva, which is also responsible for computer posting and preparation of financial statements. While the provincial treasurers also said that they were responsible for preparing annual budgets, further discussion revealed that budgets remain much the same from one year to the next, except for minor re-allocations between cost centres.

In 2005, the Auditor-General highlighted three specific difficulties in completing audits of provincial councils. First, information requested for audit purposes was either not provided in a timely manner or not produced at all. This included bank reconciliation statements and details of provincial rates collected from each tikina.

"For some councils, it has taken quite a while to produce records with numerous reminders by correspondence, electronic mail or telephone contact with the Audit Liaison Officer in the Fijian Affairs Board taking considerable time and resources.” (Office of the Auditor-General, 2005:2)

The most recent set of audited financial statements for the Namosi Provincial Council relates to 1999, while the 2000 audit is substantially complete. The audit of financial statements for 2000 was contracted to one of the big 4 accounting firms and has taken approximately two years.

Second, the supporting records from which the financial statements were prepared were not maintained satisfactorily and not always provided for audit.

"For example, in the audit of Kadavu Provincial Council 2001 accounts, the chartered accounting firm encountered difficulties in obtaining information and records to substantiate amounts in the financial statements.” (Office of the Auditor-General, 2005: 4)

This was substantiated by interviews with the provincial treasurers, which indicated that Fixed Asset Registers are not maintained at provincial level. In fact, the FAB Accounting Manual does not even mention such a register. The absence of such basic accounting records raises serious questions about basic accounting knowledge and understanding the need to be accountable for public funds. 
A third problem was delays in communication.

"Some provincial councils ... take months to have audited accounts signed by the Chairman and the Roko Tui” (Office of the Auditor-General, 2005:4)

In this regard, it is noted that none of the provincial council audits have been completed beyond 2002.

The Auditor-General has stressed the need to appoint suitably qualified officers within each provincial office (PriceWaterhouseCoopers, 2002), who can assume responsibility for preparation of financial statements, thereby permitting decentralization of the accounting function to provincial level. This was supported by the managing director of the Maxumise Consulting Agency, who recommended that the position of Provincial Treasurer should be upgraded to a Financial Officer, with the relevant qualifications and experience. Over time, the post could be upgraded to Finance Manager, subject to availability of funds for appropriate remuneration.

Apart from the issues highlighted by the Auditor-General, site visits indicate that provincial councils continue to use manual accounting systems. If these were computerized, the speed and accuracy of processing might increase significantly.

In summary, many basic processes such as the calculation of depreciation are being conducted at head office (FAB), rather than provincial level. At head office, this contributes to additional bottlenecks, resulting in a backlog of financial statements for the entire 14 provinces. The problem is exacerbated by capacity constraints within head office, where none of the ten accounting staff has a degree in accounting and none of them are members of a professional accounting body.

\section{CONCLUSION}

Among indigenous Fijians, there is an urgent need to develop a common understanding of accountability, although it is unlikely that this can be captured in a single word. The study has identified several concepts such as dodonu, matata and savasava, which offer a starting point towards a synthesis of views. Further study and discussion may contribute to a more holistic understanding of the term and avoid the misrepresentation and misinterpretation which has historically been associated with accounting and the role of accountants.

The study also documents evidence of pre-colonial structures for accounting and accountability, notably the role of the sauturaga, which is less evident in contemporary Fijian society. Further study is necessary to substantiate the role and powers of the sauturaga in different provinces throughout Fiji. This could involve consideration of how sauturaga can uphold accountability in the indigenous Fijian hierarchy. In addition, future studies can investigate the role of accounting in the context of births, deaths and marriages, during which large volumes of traditional wealth are amassed and distributed.

Many Fijians regard the Fijian Administration as a traditional structure, overlooking the fact that it was introduced by the British colonial administration, for the express purpose of controlling the indigenous population. Long after independence in 1970, the system continues to be used to generate provincial levies and monitor development projects. In this regard, indigenous Fijians are vigorously held accountable for their contributions and actually penalised for short-falls. However, there is little evidence to indicate a corresponding level of accountability by the provincial administration for the use of those funds. This dichotomy is 
consistent with the concept of colonial control, with its emphasis on autocratic decisionmaking, upward reporting, ease of aggregation and management by exception. However, it is not consistent with the concept of accountability which is an integral part of autonomous democratic societies.

Although one of the provincial councils' express responsibilities is to uphold good governance within their province, audited financial statements are not being produced in a timely manner. Financial statements are being submitted up to five years late, despite the requirement under Section 6 of Subsidiary Legislation to the Fijian Affairs Act to prepare and submit them within three months of the end of each financial year. This reflects serious problems with accounting expertise, accounting systems and understanding of accountability. To improve standards of accounting and accountability, it will be necessary to revise accounting procedures, automate accounting systems, upgrade accounting skills and decentralise accounting functions. This applies to the provincial councils as well as FAB.

It is also essential to raise the level of accounting skills among villagers through formal and non-formal education. Such training will help them to analyse financial statements and better understand how their funds have been utilised. It will also empower them to ask questions and hold the Fijian Administration accountable for use of their funds. However, traditional protocols may still impede open discussion in this regard.

While participants in the study indicated that they would like to see more detailed reporting of expenditure on capital projects, scholarships and village housing schemes, further research is required to generate a richer set of data on this issue. The present research indicates the need to disseminate a greater level of information to villagers, particularly copies of financial statements. Both the mata ni tikina and officials from the provincial office can assist in this regard, since they are the only ones who currently have access to the reports.

The study concludes that there is evidence of implied and actual accountability by indigenous Fijians in Namosi. This is supported by monitoring mechanisms established by provincial offices. On the other hand, neither the FAB nor the Namosi Provincial Council appears to take serious responsibility for accounting to indigenous Fijians in the province. Sadly, there is little evidence to demonstrate an explicit accountability to indigenous Fijians.

\section{REFERENCES}

Anon (1978) Fijian Affairs Act (Cap 120). Parliament of Fiji, Suva.

(1985) Fijian Affairs Act (Cap 120) Subsidiary Legislation. Parliament of Fiji. Suva.

Belshaw, C. S. (1964) Under the Ivi Tree: Society and Economic Growth in Rural Fiji. Routledge and Kegan Paul, London.

Burns, A. C. (1960). Report of the Commission of Enquiry into the Natural Resources and Population Trends of the Colony of Fiji. Government of Fiji, Suva.

Capell, A. (1991) A New Fijian Dictionary. Government of Fiji, Suva.

Chand, P. (2003) Relevance of International Accounting Standards to Developing Countries; The Case for Fiji. Unpublished Thesis. USP, Suva.

Cole, R. V., S. I. Levine and A. V. Matahau (1985) The Fijian Provincial Administration: A Review. Pacific Islands Development Programme, East-West Centre, Honolulu. 
Davie, S. S. K. (2000), “Accounting for imperialism: a case of British imposed indigenous collaboration,” Accounting, Auditing and Accountability Journal, Vol. 13, No. 3, pp 330 - 339

(2006)"The politics of accounting, race and ethnicity: a story of a Chiefly-based preferencing." Critical Perspectives on Accounting Vol 16, No. 5 pp 551-577.

Durutalo, A. L. (1997), Provincialism and the crisis of indigenous Fijian political unity. Unpublished Thesis. USP, Suva.

Fijian Affairs Board (1949) Standing orders for accounting made by the Board under the provisions of the Fijian Affairs Ordinance (Cap. 83) Fijian Affairs Board, Suva.

Gallhofer, S. and A. Chew (2000) "Introduction: accounting and indigenous peoples” Accounting, Auditing \& Accountability Journal, Vol. 13, No. 3, pp. 256-267

Gregory, R. (1995) “Accountability, responsibility and corruption: managing the public production process,” in Boston, J. (Ed), ‘The State under contract,” Bridget William Book’s Ltd, Wellington.

Hazlewood, D. (1914) A Fijian and English and An English and Fijian Dictionary with Examples of Common and Peculiar Modes of Expression and uses of Words. Waterlow and Sons Limited, London Wall, London.

Mamak, A. F. (1976) Namosi Data Paper. Namosi Joint Venture Consortium, Suva.

McDougall, R. S. (1957) Fijian Administration. Government of Fiji, Suva.

Ministry Of Information (2007) GCC Review Team Appointed. Press Release August 21. Fiji Ministry of Information, Suva.

Naivaluwaqa, T (2007) “Landowners want land returned.” Fiji Times Online. Friday November $2^{\text {nd }} 2007$

Namosi Provincial Council. (2006) Annual Business Plan 2007. Unpublished document, Namosi Provincial Council, Navua, Fiji.

Nayacakalou, R. R. (1975) Leadership in Fiji. USP, Suva.

Neu, D.(2000) "Accounting and accountability relations: colonization, genocide and Canada's first nations." Accounting, Auditing \& Accountability Journal Vol 13, No. 3 pp 268-288

Neu, D. and C. Graham (2004) "Accounting and the holocausts of modernity." Accounting, Auditing \& Accountability Journal Vol 17, No. 4 pp578-603

Office of the Auditor-General (2005) Auditor-General's Report to Parliament on Miscellaneous Audits/Updates. Parliament of Fiji, Parliamentary Paper Number 112 of 2005.

PriceWaterhouseCoopers (1985) Accounting Manual. Fijian Affairs Board, Suva.

(2002) Ministry of Fijian Affairs, Culture and Heritage: Review of the Fijian Administration Report Volume 1 and 2. Parliament of Fiji, Parliamentary Paper Number 70 of 2002.

Qalo, R. R. (1993) Indigenous politics in the governance of Fiji: the case of forestry. Unpublished Thesis. ANU, Canberra.

(2006) Fiji - Vanua 'o Natewa: Sustainable Decentralisation, Empowerment, Participation and Poverty Reduction Response. Unpublished Paper, USP, Suva.

Reddy, M. and R. Singh (2007) “Corporate Governance in Fiji's Native Land Trust Board” Pacific Economic Bulletin Vol. 22 No. 2 pp 36-52

Routledge, D (1975) Matanitu: The Struggle for Power in Early Fiji. Institute of Pacific Studies, USP, Suva.

Seruvakula, S. (2000) Bula Vakavanua. Institute of Pacific Studies. USP, Suva. 
The Australasian Accounting Business \& Finance Journal, February, 2008. Rika, Tuiloa, Tuiseke \& Finau-Tavite: Accounting and Accountability by Provincial Councils in Fiji. Vol. 2, No. 1. Page 35.

Sharma, S. (1999) "The Control and Protection of Native Lands in Fiji”, Journal of South Pacific Law Working Paper.

Spate, O. H. K. (1959) The Fijian People: Economic Problems and Prospects. Government Press, Suva.

Tagi, E. J. (1991) Fijian identity: a study of the prospects and problems of maintaining a Fijian identity in a multiracial society. Unpublished Thesis. USP, Suva. 


\section{Glossary of Selected Fijian Terms ${ }^{7}$}

\begin{tabular}{|c|c|}
\hline $\begin{array}{l}\text { Bose Levu } \\
\text { Vakaturaga }\end{array}$ & $\begin{array}{l}\text { "Great” Council of Chiefs; the name by which the colonially created } \\
\text { "Native” Council is currently known. Formerly it was known as Bose ni } \\
\text { Turaga }\end{array}$ \\
\hline i tokatoka & $\begin{array}{l}\text { Extended family group traced patrilinealy. In pre-colonial Fiji, the i } \\
\text { tokatoka was the basic landowning unit in some Vanuas }\end{array}$ \\
\hline Koro & $\begin{array}{l}\text { A Fijian village within which there exists such structures as the "i } \\
\text { tokatoka", "bito" or "batinilovo", "mataqali" and "yavusa". Thus, an } \\
\text { indigenous Fijian not only belongs to a koro or village but also belongs } \\
\text { to each of the three structures mentioned above. }\end{array}$ \\
\hline Mataqali & $\begin{array}{l}\text { A sub-clan which is composed of one or a number of extended families; } \\
\text { the Mataqali was used as the basic landowning unit by the British } \\
\text { colonial government. }\end{array}$ \\
\hline Matanitu & $\begin{array}{l}\text { The confederacy or the highest socio-political formation (beyond the } \\
\text { vanua) found in some parts of pre-colonial Fiji towards the end of the } \\
18^{\text {th }} \text { century. Unlike the more stable Yavusa or Vanua structures, the } \\
\text { Matanitu was composed of fragile alliances which required to be held } \\
\text { together by a main force. Matanitu existed within the context of political } \\
\text { processes and was regarded as a power construct articulated through the } \\
\text { continual exercise of force. Prior to cession, Seru Cakobau, through } \\
\text { conquests in warfare had united a number of Vanuas under the Matanitu } \\
\text { of Kubuna in Eastern Fiji. A number of Vanuas in pre-colonial Fiji, } \\
\text { especially in Western Viti Levu were not subjected under a Matanitu. } \\
\text { Routledge (1985) explained that the Matanitu was still evolving in the } \\
\text { 1700's. The process of its evolution was affected by the arrival of } \\
\text { different waves of Europeans. }\end{array}$ \\
\hline Roko Tui & $\begin{array}{l}\text { (i) a title given to the holder of a chiefly office e.g. Roko Tui } \\
\text { Namata is the highest ranking chief in the Vanua of Namata. } \\
\text { a Fijian administration official in charge of a province; the title } \\
\text { may have been used in this context since most if not all provincial } \\
\text { Roko Tui in the colonial era were chiefs. }\end{array}$ \\
\hline Tikina & $\begin{array}{l}\text { The subdivisions within one province which is usually based on the pre- } \\
\text { colonial Vanua structure. }\end{array}$ \\
\hline Vanua & $\begin{array}{l}\text { All the resources i.e. human and non-human in a defined boundary; } \\
\text { turaga ni Vanua - (i) it may refer to the chief within a defined boundary, } \\
\text { or (ii) all adult titled males within a defined boundary. }\end{array}$ \\
\hline Yasana & $\begin{array}{l}\text { The name given to the colonially created province which was composed } \\
\text { of a unity of Vanuas. The yasana was formed out of colonial necessity } \\
\text { and traditional socio-political ties. }\end{array}$ \\
\hline Yavusa & $\begin{array}{l}\text { The largest kinship group within the context of a Vanua; within a yavusa } \\
\text { there may be more than one mataqali. Routledge (1975) argued that the } \\
\text { basic unit of Fijian society was the yavusa and that all members of a } \\
\text { yavusa, in theory, claim descent from a legendary founder. }\end{array}$ \\
\hline
\end{tabular}

\footnotetext{
${ }^{7}$ These definitions are taken from Durutalo (1997).
} 